\title{
Alcohol consumption in young people between 18 and 24 years according to sociodemographic characteristics
}

\author{
María Belén Villacé ${ }^{1}$ \\ Alicia Ruth Fernández² \\ Moacyr Lobo da Costa Júnior ${ }^{3}$
}

Objective: to identify alcohol consumption in young people between 18 and 24 years of age in the province of Córdoba who participated in the National Survey of Risk Factors, according to sociodemographic characteristics. Method: a quantitative, analytic and cross-sectional study was undertaken in a sample of 240 young people. The alcohol consumption and sociodemographic characteristics were analyzed using bivariate analysis, risk ratio and confidence intervals. Results: the lifetime prevalence of alcohol consumption corresponded to $79.17 \%$, the one-year prevalence to $72.91 \%$ and the one-month prevalence to $57.08 \%$, while episodic abuse and regular hazardous consumption corresponded to $25.55 \%$ and $24.19 \%$. Consumption levels in the last month were higher among males $(p=0.0028)$, single people $(p=0.0001)$, with a secondary education degree $(p=0.0306)$. Conclusion: in the province of Córdoba, drugs use, including alcohol, has not been an area of research interest in recent years, although alcohol abuse is associated with other risk factors, like accidents and violence, and is a factor of comorbidity and early mortality. Therefore, alcohol consumption in young people represents an area of concern and, once characterized, preventive actions should be adopted.

Descriptors: Alcohol Drinking; Cross-Sectional Studies; Adolescent; Young Adult.

\footnotetext{
${ }^{1}$ Nutritionist, scholarship holder of research from Escuela de Salud Pública, Facultad de Ciencias Médicas, Universidad Nacional de Córdoba, Córdoba, Argentina.

2 PhD, Full Professor, Escuela de Salud Pública, Facultad de Ciencias Médicas, Universidad Nacional de Córdoba, Córdoba, Argentina.

${ }^{3} \mathrm{PhD}$, Associate Professor, Escola de Enfermagem de Ribeirão Preto, Universidade de São Paulo, WHO Collaborating Centre for Nursing Research Development, Ribeirão Preto, SP, Brazil.
}

Corresponding Author:

Moacyr Lobo da Costa Júnior

Universidade de São Paulo. Escola de Enfermagem de Ribeirão Preto

Departamento de Enfermagem Psiquiátrica e Ciências Humanas

Av. Bandeirantes, 3900

Bairro: Monte Alegre

CEP: 14040-902, Ribeirão Preto, SP, Brasil

E-mail: mlobojr@eerp.usp.br 


\section{Introduction}

The history of drugs and especially alcohol consumption is a psychosocial phenomenon that has always accompanied humanity ${ }^{(1)}$.

Alcohol intake is fundamentally linked to cultural patterns, many of which are related to social functions. Cultural patterns, in turn, intervene in the different ways in which people consume the available alcohol, with a possible chronic consumption related to addiction problems, or abuse, whether sporadic or not, and related to accidents and violence ${ }^{(2)}$.

Nowadays, sufficient evidence exists about alcohol consumption patterns and their relation to health. Epidemiological data show that global alcohol consumption is responsible for $3.2 \%$ of deaths and $4 \%$ of the disease burden ${ }^{(2)}$. In Argentina, it is estimated that $37 \%$ of traffic accidents in men and $47 \%$ of homicides and cases of aggression can be attributed to alcohol consumption ${ }^{(3)}$.

Traditional studies on alcohol use tend to narrow the focus to users with addiction symptoms, hiding the complex and diverse phenomenon of alcohol consumption, as improper alcohol consumption problems are hidden by addiction problems. In recent decades, however, efforts have been made to determine the start of alcohol abuse and how this consumption continuously develops towards addiction(4).

In Argentina, drugs consumption among young people and adolescents is one of the most severe public health problems. The need to get to know the evolution of the problem in that country and specially address young people is very important, as the phase they are going through is one of the most risky periods to start consumption conducts. Certain distinctive characteristics of this evolution period may enhance this fact, such as the search for autonomy and personal identity, the need to experience new feelings and the importance granted by the peer group ${ }^{(5)}$.

The alcohol consumption phenomenon demands an approach that permits a comprehensive assessment of the consequences and social impact in each community granting information and fundamental inputs for decision-making in the fields of prevention and control. In that sense, this study provides data that could serve as information sources for the design and implementation of community strategies and for the proposal of alcohol consumption prevention programs among young people in the province of Córdoba. Therefore, in this research, the aim is to identify alcohol consumption according to sociodemographic characteristics in young people between 18 and 24 years of age from the province of Córdoba who participated in the 2009 National Survey of Risk Factors.

\section{Method}

This quantitative, analytic and cross-sectional study was developed based on the secondary database of the Argentinean Ministry of Health, based on data obtained from the first National Survey of Risk Factors, held in 2009.

The household survey was representative of the nation and province and included people aged 18 years and older, selected through a probabilistic sample of residences. Based on each selected residence, households were identified and, in each household, one random person within the age range was interviewed.

Before the interview, consent was requested in compliance with the Helsinki declaration. The confidentiality of the collected data is guaranteed by the law on the confidentiality of statistics ( $\mathrm{N}^{\circ} 17.622$ ). A database was elaborated with identification codes for each interviewee, whose confidentiality was protected throughout the research process. For the present study, approval was sought from the Ethics Committee at Hospital Nacional de Clínicas of the Universidad Nacional de Córdoba (protocol 091/11).

The questionnaire for Surveillance of NonCommunicable Diseases was proposed by PAHO and was validated and adapted for use as the standard tool in risk factor surveys in Argentina. In this study, only survey participants from the province of Córdoba were considered.

The sample included all young people between 18 and 24 years of age who were surveyed in the province of Córdoba, totaling 240.

The analytic variables are grouped in the dimensions alcohol consumption and sociodemographic characteristics. The former includes the following variables: lifetime prevalence of alcohol consumption (consumption at least once in life), one-year prevalence of alcohol consumption (consumption at least once in the last twelve months), one-month prevalence of alcohol consumption (consumption at least once in the last 30 days), binge drinking (consumption of five shots or more on one occasion in the last 30 days), regular hazardous alcohol consumption (mean consumption of one shot per day in women and two shots per day 
in men in the last 30 days). The variables grouped in the sociodemographic dimension are gender, education level, marital status and occupational situation.

The variables were subject to descriptive analysis, using summary measures, absolute and relative frequencies. The data were statistically processed by applying bivariate analysis, through categorical data (Chi-square test or Fisher's test), calculating the risk ratio and confidence intervals (CI) for each research variable. In all cases, significance was set at $p<0.05$.

\section{Results}

The study sample consists of 240 young people between 18 and 24 years of age from the province of Córdoba, with a mean age of $21.13 \pm 1.9$ years.

In the analysis of the sociodemographic characteristics, it is observed that the sample includes $58.33 \%$ girls and $41.67 \%$ boys. Seventy-five percent of the population is single and $24.17 \%$ married or living with a fixed partner, while $0.83 \%$ is separated or widowed. As regards the formal instruction level, $55.83 \%$ held a secondary or higher education degree, $34.17 \%$ did not finish secondary education and $10.00 \%$ did not finish primary education. Concerning the professional situation, $56.25 \%$ is not professionally active (unemployed or inactive), while $43.75 \%$ is professionally active.

High levels of alcohol consumption are observed in the sample. The data show that more than three out of every four young people have consumed alcohol at least once in life (lifetime prevalence 79.17\%). As to the one-year prevalence, almost three out of four young people consumed alcohol in the past year
$(72.91 \%)$, against one out of two in the last month $(57.08 \%)$. Binge drinking and regular hazardous consumption are present with $25.55 \%$ and $24.19 \%$, respectively. Table 1 displays all items addressed in the consumption profile.

Table 1 - Alcohol Consumption in young people between 18 and 24 years in the province of Córdoba, Argentina, 2009

\begin{tabular}{lcc}
\hline \multicolumn{1}{c}{ Variable } & FA & $\%$ \\
\hline Lifetime prevalence $(\mathrm{N}=240)$ & 190 & 79.17 \\
One-year prevalence $(\mathrm{N}=240)$ & 175 & 72.92 \\
One-month prevalence $(\mathrm{N}=240)$ & 137 & 57.08 \\
Binge drinking $(\mathrm{N}=137)$ & 35 & 25.55 \\
Regular hazardous consumption $(\mathrm{N}=124)$ & 30 & 24.19 \\
\hline
\end{tabular}

Source: National Survey of Risk Factors

In terms of gender, the lifetime and one-year prevalence is higher among female participants, while the one-month prevalence, binge drinking and regular hazardous consumption show higher percentages among males (Table 2).

When considering all alcohol consumption variables, the highest percentage was for young people who had finished secondary education or held a higher education degree. With regard to the marital status, the highest percentages were found for single participants, exceeding $74 \%$ (Table 2 ).

The occupational situation shows differences according to the consumption variables. The absence of a professional activity (unemployed or inactive) reveals higher percentages of lifetime, one-year and one-month prevalence, whereas the percentages of binge drinking and regular hazardous consumption were higher among professionally occupied participants (Table 2 ).

Table 2 - Alcohol consumption according to sociodemographic characteristics in young people between 18 and 24 years of age in the province of Córdoba, Argentina, 2009. $(\mathrm{N}=240)$

\begin{tabular}{|c|c|c|c|c|c|c|c|c|c|c|c|}
\hline \multirow[t]{2}{*}{ Variable } & \multirow[t]{2}{*}{ Category } & \multicolumn{2}{|c|}{$\begin{array}{c}\text { Lifetime } \\
\text { prevalence }\end{array}$} & \multicolumn{2}{|c|}{$\begin{array}{l}\text { One-year } \\
\text { prevalence }\end{array}$} & \multicolumn{2}{|c|}{$\begin{array}{l}\text { One-month } \\
\text { prevalence }\end{array}$} & \multicolumn{2}{|c|}{$\begin{array}{c}\text { Binge } \\
\text { drinking }\end{array}$} & \multicolumn{2}{|c|}{$\begin{array}{c}\text { Regular } \\
\text { hazardous } \\
\text { consumption }\end{array}$} \\
\hline & & $\mathbf{n}$ & $\%$ & $\mathrm{n}$ & $\%$ & $\mathbf{n}$ & $\%$ & $\mathbf{n}$ & $\%$ & $\mathbf{n}$ & $\%$ \\
\hline \multicolumn{12}{|l|}{ Gender } \\
\hline & Male & 84 & 35 & 83 & 34.58 & 70 & 29.17 & 23 & 9.58 & 17 & 7.08 \\
\hline & Female & 106 & 44.17 & 92 & 38.33 & 67 & 27.92 & 12 & 5 & 13 & 5.42 \\
\hline \multicolumn{12}{|c|}{ Education level } \\
\hline & Finished secondary and higher & 105 & 43.75 & 103 & 42.92 & 84 & 35 & 24 & 10 & 23 & 9.58 \\
\hline & Unfinished secondary & 67 & 27.92 & 56 & 23.33 & 43 & 17.92 & 8 & 3.33 & 6 & 2.5 \\
\hline & Unfinished primary & 18 & 7.5 & 16 & 6.67 & 10 & 4.17 & 3 & 1.25 & 1 & 0.42 \\
\hline
\end{tabular}


Table 2 - (continuation)

\begin{tabular}{|c|c|c|c|c|c|c|c|c|c|c|c|}
\hline \multirow[t]{2}{*}{ Variable } & \multirow[t]{2}{*}{ Category } & \multicolumn{2}{|c|}{$\begin{array}{c}\text { Lifetime } \\
\text { prevalence }\end{array}$} & \multicolumn{2}{|c|}{$\begin{array}{l}\text { One-year } \\
\text { prevalence }\end{array}$} & \multicolumn{2}{|c|}{$\begin{array}{l}\text { One-month } \\
\text { prevalence }\end{array}$} & \multicolumn{2}{|c|}{$\begin{array}{l}\text { Binge } \\
\text { drinking }\end{array}$} & \multicolumn{2}{|c|}{$\begin{array}{c}\text { Regular } \\
\text { hazardous } \\
\text { consumption }\end{array}$} \\
\hline & & $\mathbf{n}$ & $\%$ & $\mathbf{n}$ & $\%$ & $\mathbf{n}$ & $\%$ & $\mathbf{n}$ & $\%$ & $\mathbf{n}$ & $\%$ \\
\hline \multicolumn{12}{|c|}{ Marital status } \\
\hline & Single & 142 & 59.17 & 136 & 56.67 & 113 & 47.08 & 29 & 12.08 & 27 & 11.25 \\
\hline & Married or fixed partner & 46 & 19.17 & 37 & 15.42 & 22 & 9.16 & 6 & 2.5 & 3 & 1.25 \\
\hline & Separated, divorced, widowed & 2 & 0.84 & 2 & 0.84 & 2 & 0.84 & 0 & 0 & 0 & 0 \\
\hline \multicolumn{12}{|c|}{ Occupational situation } \\
\hline & No activity & 110 & 45.83 & 98 & 40.83 & 70 & 29.17 & 16 & 6.67 & 14 & 5.83 \\
\hline & Professionally active & 80 & 33.33 & 77 & 32.08 & 67 & 27.92 & 19 & 7.92 & 16 & 6.67 \\
\hline Total & & 190 & 79.17 & 175 & 72.92 & 137 & 57.08 & 35 & 14.58 & 30 & 12.5 \\
\hline
\end{tabular}

Source: National Survey of Risk Factors

The analysis of recent alcohol use, related to the consumption in the last 30 days or one-month prevalence, is displayed in Table 3. The data show the predominance of male participants, with two male consumers for every female $(p=0.0028)$. As regards the formal education level, young people with a secondary or higher education degree show higher one-month prevalence degrees $(p=0.0306)$, and single participants reveal higher prevalence percentages than people who live in pairs (married or fixed partner) $(p=0.0001)$. The analysis of the employment situation indicates a higher one-month prevalence for participants who are not professionally active $(p=0.003)$.

Alcohol consumption associated with abuse in the last 30 days takes the form of binge drinking and regular hazardous consumption, for which data are displayed in Table 4. As observed, both are more frequent in male, single and professionally active young people with a secondary or higher education degree.

Table 3 - Prevalence of one-month alcohol consumption according to sociodemographic characteristics in young people between 18 and 24 years in the province of Córdoba, Argentina, 2009. $(n=137)$

\begin{tabular}{|c|c|c|c|c|c|c|c|}
\hline Variable & Category & $\mathbf{N}$ & $\%$ & Sig. & OR & & \\
\hline \multirow[t]{3}{*}{ Gender } & & & & 0.0028 & 2.84 & 1.42 & 5.65 \\
\hline & Male & 70 & 51.09 & & & & \\
\hline & Female & 67 & 48.91 & & & & \\
\hline \multirow[t]{3}{*}{ Education level } & & & & 0.0306 & 2.14 & 1.07 & 4.27 \\
\hline & Finished secondary and higher & 84 & 61.31 & & & & \\
\hline & $\begin{array}{l}\text { Unfinished primary and unfinished } \\
\text { secondary }\end{array}$ & 53 & 38.69 & & & & \\
\hline \multirow[t]{3}{*}{ Marital status } & & & & 0.0001 & 10.37 & 6.19 & 17.37 \\
\hline & Single & 113 & 82.48 & & & & \\
\hline & Married or fixed partner & 24 & 17.56 & & & & \\
\hline \multirow[t]{3}{*}{ Occupational situation } & & & & 0.0028 & 2.84 & 1.42 & 5.65 \\
\hline & No activity & 70 & 51.09 & & & & \\
\hline & Professionally active & 67 & 48.91 & & & & \\
\hline
\end{tabular}

Source: National Survey of Risk Factors

Table 4 - Binge drinking and regular hazardous consumption of alcohol according to sociodemographic characteristics in young people between 18 and 24 years in the province of Córdoba. ENFR 2009

\begin{tabular}{|c|c|c|c|c|c|}
\hline \multirow[t]{2}{*}{ Variable } & \multirow[t]{2}{*}{ Category } & \multicolumn{2}{|c|}{$\begin{array}{l}\text { Binge drinking } \\
(\mathrm{N}=35)\end{array}$} & \multicolumn{2}{|c|}{$\begin{array}{l}\text { Regular hazardous } \\
\text { consumption }(\mathrm{N}=30)\end{array}$} \\
\hline & & $\mathbf{n}$ & $\%$ & $\mathbf{n}$ & $\%$ \\
\hline \multicolumn{6}{|l|}{ Gender } \\
\hline & Male & 23 & 65.71 & 17 & 56.67 \\
\hline & Female & 12 & 34.29 & 13 & 43.33 \\
\hline \multicolumn{6}{|l|}{ Education Level } \\
\hline & Finished secondary and higher & 24 & 68.57 & 23 & 76.67 \\
\hline & Unfinished primary and Unfinished secondary & 11 & 31.43 & 7 & 23.33 \\
\hline
\end{tabular}


Table 4 - (continuation)

\begin{tabular}{|c|c|c|c|c|c|}
\hline \multirow[t]{2}{*}{ Variable } & \multirow[t]{2}{*}{ Category } & \multicolumn{2}{|c|}{$\begin{array}{l}\text { Binge drinking } \\
\quad(\mathrm{N}=35)\end{array}$} & \multicolumn{2}{|c|}{$\begin{array}{l}\text { Regular hazardous } \\
\text { consumption }(\mathrm{N}=30)\end{array}$} \\
\hline & & $\mathbf{n}$ & $\%$ & $\mathbf{n}$ & $\%$ \\
\hline \multicolumn{6}{|l|}{ Marital status } \\
\hline & Single & 29 & 82.86 & 27 & 90 \\
\hline & Married or fixed partner & 6 & 17.14 & 3 & 10 \\
\hline \multicolumn{6}{|c|}{ Occupational situation } \\
\hline & No activity & 16 & 45.71 & 14 & 46.67 \\
\hline & Professionally active & 19 & 54.29 & 16 & 53.33 \\
\hline
\end{tabular}

Source: National Survey of Risk Factors

\section{Discussion}

The sociodemographic characteristics of the young people between 18 and 24 years in the province of Córdoba show that the population contains more women, that three out of four young people are single, and that more than half hold a secondary or higher education degree. Concerning the occupational situation, no large percentage differences are found between professionally active (56.25\%) and inactive (43.75\%) people.

The data show a sociodemographic profile characteristic of the evolutionary period of adolescenceyouth, which in Latin societies is related to the search for autonomy and personal identity, to the need to experience new feelings. In that sense, the bibliography indicates this period as one of the most risky in terms of consumption conducts ${ }^{(6-8)}$. Alcohol is one of the most used drugs in different American regions and around the world and, according to WHO, America ranks second in alcohol consumption levels ${ }^{(9-10)}$.

The results related to alcohol consumption in the province of Córdoba show that the lifetime prevalence of alcohol consumption is similar to the results found for young people in Argentina and Latin American

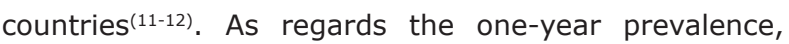
scores are higher than in studies involving young people from American countries ${ }^{(6,13)}$. The consumption on at least one occasion in the last 30 days expresses the current alcohol consumption level, with higher levels in this study than in studies of young people in Argentina(13). Its relation with the sociodemographic characteristics can reveal important implications for public health.

The analysis of the consumption levels and characteristics in different regions, countries and cultures reveals that consumption rates are higher among male than female participants(10). The results found in this study are in accordance with the bibliographic findings, showing a higher prevalence of alcohol consumption in the last 30 days among men. It has been defended over the years that the cause of this phenomenon should be sought in the double morals, which censors male abuse less strictly than female abuse, as well as in the traditional role of alcohol as a symbol of masculinity ${ }^{(14)}$.

Nevertheless, quite many women consume alcohol frequently. This situation among women was also found in other Latin American countries ${ }^{(15-16)}$. The increasing consumption of alcoholic beverages can be associated with growing female independence and greater participation in professional spheres. As a result, the condition of female emancipation may influence the development of habits that used to be predominant among men ${ }^{(17)}$.

The group holding a secondary or higher education degree showed a higher one-month prevalence than young people with lower education levels. Based on the bibliography, however, no relation has been defined between education and alcohol consumption(18-19). Other social, professional, cultural and religious factors probably combine with education, influencing the populations' alcohol consumption profile.

In the present study sample, most participants who consumed drugs in the past 30 days are single, in line with the results from a study among college students $^{(11-20)}$. In Argentina, data about young college students show greater addiction problems in this phase of life and in single people ${ }^{(10)}$. This is in accordance with the results for binge drinking and regular hazardous consumption, equal to $82.86 \%$ and $90 \%$, respectively, in single young people.

Little attention has been paid in research to the relation between alcohol and the professional situation. Data for adolescents in Argentina and Brazil show a higher prevalence of recent alcohol consumption among students who worked(5,21-22). In the present study, the prevalence levels of consumption in terms of occupation vary according to the consumption pattern. The higher prevalence of alcohol consumption in young people who are not professionally active is found for lifetime, one-year and one-month consumption. On the other hand, a higher prevalence of binge drinking and regular 
hazardous consumption is observed among young people who are professionally active, which may mean that abuse and risk patterns are associated with the availability of money.

The consumption of at least four/five standard shots on one occasion in female and male participants is called binge drinking internationally and episodic excessive use in Argentina. It is important to identify binge drinking in the population, as this behavior comes with physical and emotional health problems and is associated with violence, accidents, fights and homicides(23). Acknowledging binge drinking levels in the population should serve as an alert to the different social consequences it can provoke.

Binge drinking, especially among young people, is particularly high in many Latin American countries ${ }^{(13,24)}$. The prevalence of binge drinking (related to the population that consumed drugs in the last month) shows that one out of every four young people indicated at least one occasion of binge drinking, similar to data in

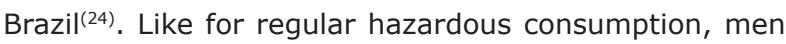
revealed higher consumption levels.

The rate of regular hazardous consumption in young people from Córdoba is $12.50 \%$. When considering the population that consumed drugs in the past 30 days, however, the prevalence of regular hazardous consumption reaches $24.19 \%$.

\section{Conclusion}

The present study results show that the prevalence of alcohol consumption is high among young people between 18 and 24 years of age in the province of Córdoba, who participated in the ENFR. The prevalence of alcohol consumption in the last 30 days was high, including binge drinking and regular hazardous consumption.

Regarding gender, among the young people who participated in this study, the prevalence of lifetime alcohol consumption and one-year consumption was higher among females, while that of one-month consumption, binge drinking and regular hazardous consumption was higher among males.

Among the young people from Córdoba who participated in the ENFR, the highest consumption levels were found among participants with a secondary or higher degree and among single people. As regards the occupational situation, differences were found, with higher prevalence levels of lifetime, one-year and one-month consumption among participants who were not professionally active, and higher levels of binge drinking and regular hazardous consumption among professionally active young people.

In the province of Córdoba, drugs use, including alcohol, has not been an area of research interest in recent years, although alcohol abuse is associated with other risk factors, like accidents and violence, and is a factor of comorbidity and early mortality. Therefore, alcohol consumption in young people represents an area of concern and, once characterized, preventive actions should be adopted.

This study comes with different limitations, which could be solved in future longitudinal studies and trend analyses. It would also be interesting to complement the research, considering other important variables in the description of alcohol consumption.

\section{Acknowledgements}

To the National Secretary of Drugs Policies (SENAD) of the Institutional Safety Cabinet/Brazil, to the University of São Paulo at Ribeirão Preto College of Nursing and the WHO Collaborating Centre for Nursing Research Development, to the members of the Research Center at the School of Public Health of the Faculty of Medical Sciences at Universidad Nacional de Córdoba, to the population represented in the research and to the management, faculty, staff and colleagues of the On-Line Specialization Program on Research about the consumption of Alcohol and Other Psychoactive Drugs 2011-2012.

\section{References}

1. González V, Sepúlveda J, Gaete J. El alcoholismo social: apuntes para un enfoque integral. Rev Centroamericana Cienc Salud. 1976;2(4):25-54.

2. World Health Organization. Quantifying selected major risks to health. World Health Report - Chapter four. 2002. [acesso 1 mar 2012]. Disponivel em: http:// www.who.int/whr/2002/chapter4/en/index.html\#

3. Ministerio de Salud (AR). Experiencias en la prevención y control del consumo de alcohol. 2010. [acesso $1 \mathrm{mar}$ 2012]. Disponivel em: http://msal.gov.ar/htm/site/ enfr/contenidos/PDF/publicacion_alcohol.pdf

4. Míguez $H$. Uso de sustancias psicoactivas. Buenos Aires: Paidos; 1999. 168 p.

5. Secretaría de Programación para la Prevención de la Drogadicción y la Lucha Contra el Narcotráfico (AR). Estudio acerca del consumo de sustancias psicoactivas en estudiantes universitarios del interior del país. Argentina. 2006. [acesso 1 mar 2012]. Disponivel em: http:// www.asociacionantidroga.org.ar/superint/Estadisticas/ 
Estudio\%20sobre\%20Consumo\%20de\%20sustancias $\% 20$ en $\% 20$ Universitarios $\% 20$ por\%20Regiones $\% 20$ 2006.pdf

6. Urquieta JE, Hernández-Ávila $M$, Hernández $B$. El consumo de tabaco y alcohol en jóvene de zonas urbanas marginadas de México. Un análisis de decisiones relacionadas. Salud Publica Mex. 2006;48(1):30-40.

7. Espada JP, Pereira JR, García-Fernández J. Influencia de los modelos sociales en el consumo de alcohol de los adolescentes. Psicothema. 2008;20(4):531-7.

8. Verra F, Zabert G, Ferrante D, Morello P, Virgolini M. Consumo de tabaco en estudiantes de educación secundaria de Argentina. Rev Panam Salud Publica. 2009;25(3):227-33.

9. Inter-American Drug Abuse Control Commission (OAS Official Records Series; O EA Ser. L). Report on drug use in the Americas; 2011. OEA/Ser.L/XIV.6.6. Washington, D.C; 2012.

10. Secretaría de Programación para la Prevención de la Drogadicción y la Lucha Contra el Narcotráfico (AR). Diagnóstico de la Problemática del Uso Indebido de Sustancias Psicoactivas en Argentina. Argentina. 2007. [acesso 20 mar 2012]. Disponível em: http://www. observatorio.gov.ar/investigaciones/Diagnostico_de_la_ Problematica_del_Uso_de_In_2007.pdf

11. López Maldonado MC, Villar Luis MA, Gherardi Donato ECS. Licit drugs consumption among nursing students at a private university in Bogotá, Colombia. Rev. LatinoAm. Enfermagem. 2011;19(Spec):707-13.

12. Ortega Pérez CA, Costa ML, Pereira Vasters G. Epidemiological profile of drug addiction in college students. Rev. Latino-Am. Enfermagem. 2011; 19(Spec):665-72

13. Acosta LD, Fernández AR, Pillon SC. Social risk factors for alcohol use among adolescents and youth. Rev. Latino-Am. Enfermagem. 2011;19(Spec):771-81.

14. Alonso Fernández, F. Alcohol dependencia. Madrid: Editorial Pirámide; $1981.161 \mathrm{p}$.

15. Bortoluzzi MC, Traebert J, Loguercio A, Kehrig RT. Prevalência e perfil dos usuários de álcool de população adulta em cidade do sul do Brasil. Ciênc Saúde Coletiva. 2010;15:679-85.

16. Galduróz JCF, Carlini EA. Use of alcohol among the inhabitants of the 107 largest cities in Brazil - 2001. Braz J Med Biol Res. 2007;40(3):367-75.

17. Kerr-Corrêa F, Tucci AM, Hegedus AM, Trinca LA, Oliveira JB, Floripes TMF, et al. Drinking patterns between men and women in two distinct Brazilian communities. Rev Bras Psiquiatria. 2008;30(3):235-42.

18. Dias-da-Costa JS, Silveira MF, Gazalle FK, Oliveira
SS, Hallal PC, Menezes AMB, et al. Consumo abusivo de álcool e fatores associados: estudo de base populacional. Rev Saúde Pública. 2004;38(2):284-91.

19. Almeida-Filho N, Lessa I, Magalhães L, Araújo MJ, Aquino $\mathrm{E}$, Kawachi I, et al. Alcohol drinking patterns by gender, ethnicity, and social class in Bahia, Brazil. Rev Saúde Pública. 2004;38(1):45-54.

20. Pillón SC, Dos Santos MA, Martins de Souza Gonçalves A, Araújo KM, Funai A. Fatores de risco, níveis de espiritualidade e uso de álcool em estudantes de dois cursos de enfermagem. SMAD, Rev. Eletrônica Saúde Mental Álcool Drog. (Ed. port.). 2010 Nov; [acesso 25 mar 2013]. 6(Especial):493-13. Disponivel em: <http:// pepsic.bvsalud.org/scielo.php?script $=$ sci_arttext\&pid $=S$ $180669762010000300008 \&$ lng $=p t \& n r m=i s o>$.

21. Souza DPO, Silveira Filho DX. Uso recente de álcool, tabaco e outras drogas entre estudantes adolescentes trabalhadores e não trabalhadores. Rev Bras Epidemiol. 2007;10(2):276-87.

22. Soledad Burrone M, Villela SMV, Costa ML Enders J, Fernández AR, Vasters GP. Analysis of the frequency of experimentation with and consumption of drugs in high-school students. Rev. Latino-Am. Enfermagem. 2010;18(Spec):648-54.

23. Obot I, Room R. Alcohol, Gender and Drinking problems: perspectives from low and middle income countries. Genéve: Organización Mundial de la Salud; 2005.

24. Balan TG, Campos CJG. Padrão de consumo de bebidas alcoólicas entre graduandas de enfermagem de uma universidade estadual paulista. SMAD, Rev. Eletrônica Saúde Mental Álcool Drog. (Ed. Port.). [acesso 20 mar 2012]. 2006;(2). Disponivel em: em:http:// pepsic.bvsalud.org/scielo.php?script $=$ sci_arttext\&pid $=S$ $180669762006000200003 \& \mathrm{lng}=\mathrm{pt \& nrm}=$ iso. 